\title{
Newspaper Reportage and Its Effect towards Enhancing Agricultural and Environmental Sustainability in Nigeria
}

\author{
*Ayodeji Aiyesimoju **Samuel Awoniyi \\ *Department of Mass Communication \\ **Department of Agricultural Economics and ExtensionJoseph Ayo Babalola University, Ikeji Arakeji, \\ Osun Sate, Nigeria
}

\begin{abstract}
This study examined the coverage of agriculture and environment in Nigerian newspapers using content analysis and empirical review. The (content) analysis of environmental reportage was carried out in three newspapers: The Punch, The Guardian and The Sun between August and September (2011) to back up the studies reviewed as carried out by Ifenkwe (2008) and Okorie and Oyedepo (2011). The review backed up by the fresh study further revealed the extent with which newspapers influence public knowledge and actions. Both studies reviewed had similar recommendations; that the press should improve its advocacy role by paying more attention to reportage of developmental issues. Furthermore, based on the author's fresh findings, it was observed that issues on agriculture did not receive favorable coverage by the newspapers. Three basic issues of national/global interest were selected to ascertain their degree of importance in the three newspapers studied: The Punch, The Guardian and Nigerian Tribune. The issues selected were the most reported issues at the time of study, they are: Gaddafi's capture, Boko Haram and Environment. 151 stories out of a total of 454 stories analysed making 33.2\% was allotted to environment, 97 (21.3\%) stories were published on Gaddafi's trail and capture while Boko Haram had 206 (45.4\%) stories reported. Thus, similar to the papers studied; this paper suggests that the press should endeavor to give adequate attention to various issues on agriculture as well as its developmental programs in its reportage and to intensify efforts on setting environmental agenda so as to facilitate sustainable development in agriculture and environment.
\end{abstract}

Keywords: Agriculture, environment, sustainability, development, newspaper reportage

\section{Introduction}

Discussions revolving around agriculture and environment have been fore across the globe because of the important roles of their interplay in the economy and existence of humanity as well as the inherent aftermath and dangers unethical environmental and agricultural practices can cause humanity. The press has gone a long way in setting the agenda around these two issues of pertinence globally. The media has contributed to the political, economic, cultural, educational, agricultural and social growth and development of the society.

The mass media roles in the attainment of desired development(s) cannot be overemphasized especially through various levels of coverage they give to such developmental subjects over time. The media has been identified as a major determinant of public enlightenment and opinion. In his position, Cutlip (1992) in Utulu (2009:36), "the force of public opinion has steadily gained strength around the world as Mass Communication has become a global phenomenon".

There have been various topical issues raised on the subjects of environment and agriculture in Africa especially in Nigeria: the recent series of flooding, incessant unexpected rainfalls, harsh weather conditions, food shortage, land use, mitigation and adaptation processes among others. Even the global issue of climate change has brought about the use of the media as a conduit through which environmental and agricultural education is passed to the masses. Various mass media contents have been passed through various media structures (newspapers in the case of this study) in form of news, editorials, and features and so on.

The educational and informational roles newspapers play in these areas are thus being analysed to see how news reportage have enhanced the sustainable development of agriculture.

Against the backdrop of the background of this study, the researchers seek to find out what role the Nigerian newspapers play as development communication media in reporting agricultural and environmental activities, policies and programmes and how they perform such role in terms of the slant and prominence or importance given to issues in both areas. Furthermore, the study seeks to determine if the newspaper reports on agricultural sector as an arm of Nigeria economy were adequately represented or whether all the sub-sectors of agriculture attracts press coverage. It also seeks to look at how the Nigerian Press joined the world press in reporting environmental issues and canvassing for a green economy.

From the foregoing, the study has been designed to answer the following research questions: First, what is the volume of coverage given to agricultural activities or programmes by the Nigerian newspapers; second, what is the volume of reportage given to environment by the Nigerian newspapers; third, what is the 
volume of coverage given to other areas of economic activities by the Nigerian newspapers; fourth, what is the degree of prominence given to issues reported about agriculture; fifth, what is the degree of prominence given to issues reported about environment by the newspapers?

\section{Empirical Review}

The media has become an essential part of our lives; an average Nigerian has at least daily inevitable contact with the media at any of the levels. Going by Okorie and Oyedepo (2011:27),

the media played most significant roles towards promoting the political, social and economic aspirations of the nation (Uche, 1989). In the context of sustainable development, the press or mass media remains a vital instrument in realization of nations' goals. It is believed that the media motivate the people as well as ensure participation in the growth and developmental process apart from informing and educating members of the society.

As part of her surveillance role in respect to information and news, the media being instrument of development is expected to inform and educate members of the society on specific areas of development which ordinarily includes agricultural activities. Specifically, agriculture has provided employment platform for majority particularly people living in the rural areas. Agriculture by estimation, accounted for over $80 \%$ of Nigeria's Gross Domestic Product (GDP) prior to the discovery of crude oil (Kuye, 2004). By 2005, the percentage has reduced to $41 \%$ (Odunlami, 2007) as cited by Okorie and Oyedepo 2011.

In addition, agriculture has been considered as the backbone for rural, social and economic development. Rural development is a direct function of agricultural development without which the later becomes a mirage (Kuye, 2004).

However, beyond information and transmission role of the media, the newspaper provides to a large extent background details relevant to the news, explanations of related events, analysis of their importance and implications. The newspapers possess the capacity to do this better than most other media (Dennis and Defleur, 1994). Importantly, in a true agrarian or agricultural society, the role of the media is largely insignificant (Black et al., 1995).

The study sought to look into reportage volume level of reportage of agricultural activities shows that agricultural programmes in the period of study got $17.7 \%$ which is relatively low to several other sectors of the nation's economy, the second question is answered as environmental reports garnered 33.2\%, rating second highest of the issues studied. This portrays part of the media's Social Responsibility in readiness to put Nigeria on the Voyage to greenness.

On the volume of coverage given to other areas of economic activities by the Nigerian newspapers, Oil and Gas had 900 reports, making 21.3\%, commerce and industry; 1,120 making $26.5 \%$ and politics had1450 stories giving it $34.3 \%$.

On the degree of prominence given to issues reported about agriculture, $114(13.8 \%)$ made the front pages, $610(81.3 \%)$ were placed in inside pages and $36(4.8 \%)$ on back pages of the various issues studied. The front page shows more prominence, the back page comes next and inside pages are seen to be less prominent.

Another research work Assessment of Newspaper Advocacy for Rural Development and Environmental Education in Nigeria carried out by Ifenkwe (2008) was also reviewed. In his opinion, "newspapers need to improve on their advocacy role in order to enhance their credibility as promoters of issues of public interest." The study examined the degree of performance of newspapers in informing and educating the people on their environment and championing the rights of the people in rural development in the year 2006. Five newspapers with wide coverage were studied for duration of twelve months to ascertain the reportage level of environmental and rural development issues. The newspapers studied are: The Champion, The Sun, ThisDay, The Guardian, and the Punch. It was revealed by the study that: rural development news coverage was highest $(31.48 \%)$ in the fourth quarter, and least in the third quarter (17.79\%) of the year. Sixty nine percent of rural development information/news appeared as features, while others were presented as editorials $(13.04 \%)$, advertorials $(9.27 \%)$ and pictorials $(8.38 \%)$. The Sun newspapers $(23.65 \%)$ could easily pass as the best print medium in reporting environmental and rural development news, followed by The Punch $(22.5 \%)$ and The Champion (21.3\%) newspapers. The Sun newspapers also exhibited consistent leadership in promoting activities in the health and population / family planning sub-sectors, while The Champion disseminates more information on rural infrastructures and environmental matters.

The research work basically advocates that "newspapers need to improve on their advocacy role in order to enhance their credibility as promoters of issues of public interest".

\section{Materials and Methods}

Having reviewed related and relevant studies, the researcher uses content analysis to corroborate the findings of the empirical review. Importantly, content analysis in communication research is regarded as a formal system, systematic and objective used for extracting all forms of communication contents. Content analysis is simply the use of quantitative measurements based on frequency to examine any form of 
communication that has taken place thereby making necessary inferences (Aiyesimoju 2010:59). Therefore, content analysis was used in this study as a tool to extract data from the content of the selected newspapers. This was done by analyzing the frequency and prominence or importance as well as direction/slant of news on agricultural and environmental activities as content categories. More so, the unit of measurement and news analysis included features, news stories, editorials, special reports and sources of news, etc.

In the context of this study, there is no doubt that it is impracticable to study over 50 daily newspapers considering the time frame, constraint and most especially unavailability of some of the members of the population to the researcher is another reason. Therefore, only 3 newspapers were selected for the study, namely: The Guardian, The Punch and Daily Sun. The 3 newspapers used for the analysis; The Punch, The Guardian and Daily Sun were selected using purposive sampling technique also based on their popularity and wide readership. The two months selected for study is based on availability as those were the only months that had all issues in the period complete. All issues in this population were however sampled for authenticity especially since the number is not too large.

Thus, a sample size of 183 issues was used for the study at 61 issues per newspaper for two months.

On the one hand, the parameters for this study unit of analysis in collecting data included the various categories of media content: news, stories, features articles, editorials, special reports and news sources, etc. In addition, in terms of content(s) of the units of analysis, frequency and prominence, etc was tested. In the case of frequency, it was determined or tested based on the volume of reports on issues about agriculture and environment vis-à-vis other sectors of the economy. On the other hand, the prominence was determined by the specific position/placement of each item on the subjects of discourse issues essentially on pages of the newspaper. In other words, those that appeared on the front pages for instance was regarded as more important while those that appeared on the back pages was regarded as second in importance compared to the front page stories. Consequently, the inside page in terms of prominence was regarded as the least important.

\section{Results and Discussions}

The data analysis of this research work was based on the 454 news items content analyzed to measure environmental reportage. The frequency was based on various newspaper reports in the various units of analysis on environment in The Punch, The Guardian and Daily Sun from August $1^{\text {st }}$ till September $30^{\text {th }}$. In addition, the data was analyzed with the use of simple percentage and frequency tables: (f/t X 100) with $\mathrm{f}$ being the frequency, divided by the total number of stories and multiplied by100. This study in general terms was aimed to find out the attention given by the Nigerian press to environmental issues or matters.

In the study, three basic issues were selected to measure the degree of importance accorded each one. The issues selected were the most reported issues at the time of study, they are: Gaddafi's capture, Boko Haram and Environment. Gaddafi's trail and capture and Boko Haram (a terrorist group in Nigeria) were fore issues in the media agenda during the studied period. 151 stories out of a total of 454 stories making $33.2 \%$ was allotted to environment, 97 (21.3\%) stories were published on Gaddafi's trail and capture while Boko Haram had 206 (45.4) stories reported on it. Environmental reporting has the second highest number of reports, ranking above the Gaddafi saga and below the Boko Haram issue. The level of reportage of environmental issues got may not be farfetched as the studied period witnessed floods and court hearings on oil spills especially in Ogoni land in Bayelsa State. It however shows that the media is on course in helping to stem the tides of environmental degradation as some of the stories as seen in table 7 were on environmental education. It also shows the corrective role of newspapers as development communication media in the reorientation and mobilization of the masses towards ethical environmental practices. It was also observed that corrective reports were more in the examined issues for environment.

Environmental reporting had a low degree of prominence as it was allotted only $5.3 \%$ while inside pages took the remaining 94.7\%.From the fore going, it is recommended that the press should make more significant efforts to set agenda and mobilize the masses towards agricultural and environmental development and sustainability through information dissemination and packaging of reports. A higher level of prominence should be given to both subjects due to the crucial natures they have. Noteworthy is the fact that the dangers of illicit agricultural and environmental practices pose higher threats and risks than terrorism and unrest as it is now. In essence, sufficient attention should be given to agricultural and environmental sustainability matters by the Nigerian press.

Furthermore, the press should adequately utilize its developmental and social responsibility theory/function for the positive change and development of the agricultural and environmental sector.3 

V.

Tables and Figures

Table 1. Number and Percentage of news reported on Environment viz-a-viz two other issues of high prominence

\begin{tabular}{|l|l|l|l|l|l|l|l|l|l|}
\hline \multirow{2}{*}{$\begin{array}{l}\text { News } \\
\text { Categories }\end{array}$} & \multicolumn{4}{|c|}{ Punch } & Guardian & \multicolumn{3}{c|}{ Daily Sun } \\
\cline { 2 - 10 } & Aug. & Sept. & Total & Aug. & Sept. & Total & Aug. & Sept. & Total \\
\hline Boko Haram & 29 & 33 & $62(47 \%)$ & 14 & 48 & $62(30.5 \%)$ & 32 & 50 & $82(51 \%)$ \\
\hline Gaddafi & 17 & 21 & $38(28.8 \%)$ & 12 & 18 & $30(18.6 \%)$ & 19 & 10 & $29(18 \%)$ \\
\hline Environment & 20 & 12 & $32(24.2 \%)$ & 38 & 31 & $69(43 \%)$ & 19 & 31 & $50(31.1)$ \\
\hline Total & 66 & 76 & $132(100 \%)$ & 64 & 97 & $161(100 \%)$ & 70 & 91 & $161(100 \%)$ \\
\hline
\end{tabular}

Table 2. Number of local and foreign environmental reports and sub-sets of local environmental reports

\begin{tabular}{|c|c|c|c|c|c|c|c|}
\hline & Foreign & \multicolumn{6}{|l|}{ Local } \\
\hline & & Flood & $\begin{array}{l}\text { Otherdisast } \\
\text { ers }\end{array}$ & Oil Spills & $\begin{array}{l}\text { Filth/Dum } \\
\text { ps }\end{array}$ & $\begin{array}{l}\text { Env.Education/G } \\
\text { ov't Policy }\end{array}$ & Total \\
\hline Punch & $\begin{array}{l}2(6.25 \\
\%)\end{array}$ & $\begin{array}{l}15(46.9 \\
\%)\end{array}$ & $2(6.3 \%)$ & $5(15.6 \%$ & $2(6.25)$ & $6(18.8)$ & $\begin{array}{l}32(100 \\
\%)\end{array}$ \\
\hline $\begin{array}{l}\text { Guardia } \\
\text { n }\end{array}$ & $\begin{array}{l}8(11.6 \\
\%)\end{array}$ & $\begin{array}{l}18(20.1 \\
\%)\end{array}$ & $\operatorname{Nil}(0 \%)$ & $\begin{array}{l}17(24.6 \\
\%)\end{array}$ & $\begin{array}{l}\operatorname{Nil}(0 \% \\
\text { ) }\end{array}$ & $26(37.7)$ & $\begin{array}{l}69(100 \\
\%)\end{array}$ \\
\hline Sun & $1(2 \%)$ & $31(62 \%)$ & $4(8 \%)$ & $10(20 \%)$ & $\begin{array}{l}\operatorname{Nil}(0 \% \\
)\end{array}$ & $4(8 \%)$ & $\begin{array}{l}50(100 \\
\%)\end{array}$ \\
\hline
\end{tabular}

Table 3. Level of prominence given to environmental reports by pagination

\begin{tabular}{|l|l|l|l|l|}
\hline & Punch & Guardian & Sun & Total \\
\hline Front & 4 & 4 & Nil & $8(5.3)$ \\
\hline Inside & 28 & 65 & 50 & $143(94.7)$ \\
\hline Back & Nil & Nil & Nil & Nil $(0 \%)$ \\
\hline Total & 32 & 69 & 50 & 151 \\
\hline
\end{tabular}

\section{References}

[1.] Aiyesimoju (2010) Public Enlightenment as a Tool for National Development: The Roles of Nigerian Newspapers, Unpublished Undergraduate Thesis.

[2.] Ifenkwe (2008) Assessment of Newspaper Advocacy for Rural Development and Environmental Education in Nigeria. Journal of Agricultural Extension Vol. 12 (2), pp. 41-51.

[3.] Okorie and Oyedepo (2011) Newspaper Reportage and its Effect Towards Promoting Agricultural Development in Nigeria. Journal of Media and Communication Studies Vol. 3(2), pp. 27-32.

[4.] Utulu (2009) Between Public Opinion and Media Agenda of Political Issues in Nigeria. International Journal of Social and Management Sciences Vol.1(1) pp. 35-54 